\title{
RELIGION AND MULTICULTURALISM AT PESANTREN SUNAN PANDANARAN AND MUALLIMIN YOGYAKARTA
}

\author{
Niswatin Faoziah, Hasan Mahfudh \& Rima Ronika \\ College of Islamic Studies Sunan Pandanaran Yogyakarta \\ niswatinfaoziah@yahoo.co.id
}

\begin{abstract}
This paper discusses the role of pesantren (Islamic boarding school) education in developing multicultural values at Sunan Pandanaran and Muallimin Pesantren Yogyakarta. Through field studies, the findings of this research are: First, the multicultural values are reflected and have become good principles at Sunan Pandanaran or Muallimin Pesantren Yogyakarta despite the difference in characteristics. Second, pesantren education --both at Sunan Pandanaran and Muallimin Pesantren Yogyakarta-- have an important contribution to the development of multicultural values each with different traits and characteristics. Third, some teachers with little understanding of multiculturalism have become a major obstacle in pesantren education especially with regard to the multicultural values. Moreover, in the context of multicultural education curriculum development, the dilemma of self-identity also becomes another problem.
\end{abstract}

Keywords: Pesantren; multicultural education; Sunan Pandanaran; Muallimin Yogyakarta

\section{INTRODUCTION}

Several years ago, we witnessed tragedies of ethnic / religious violence that occurred in Ambon, Sambas, Sampit, Poso, which are not impossible to happen again in the future. In addition, there have been frequent attacks on minority ethnic / religious groups, such the expulsion of Shias in Madura, church burnings, and the indiscriminate attacks against members of LDII in Parung Bogor. These are examples of the gloomy face of the country. The violence and the conflict have in fact caused not only loss of a lot of lives and material, but also disharmony between different communities. Needless to say that plurality in society is like a two bladed sword. On the one hand, it is a wealth of the country that should be maintained, but on the other hand, it could be a trigger factor of horizontal conflicts. ${ }^{1}$

${ }^{1} \mathrm{M}$, Jandra, "Islam in the Context of Culture and Tradition Plural", in the book, Zakiyudin Baidhawi, ed., Religion and Plurality of Local Culture, (Surakarta: Muhammadiyah 
Plurality or human plurality is in fact the will of Allah. The Qur'an says that humans were created nations and tribes so that they know and appreciate each other. ${ }^{2}$ Normative Islam (Qur'an and Sunnah) always teaches its believers to behave well, respect each other and visit each other, deliberate, socialize and forbids them to be evil, arrogant, envious, anarchistic, etc. Therefore, an attempt to make Islam a social integrity becomes a necessity. So it is necessary to study the elements that can unite cultures, and most importantly, raise awareness of cultural unity. ${ }^{3}$ If the norms of Islam are practiced well, they will certainly give birth to a good community and nation. However, the norms could be contrary in practice. There is often a gap between ideals and reality, between normative Islam and historical Islam mainly related to culture, tradition, views of scholars, and confidence in the non-Muslims in Indonesia. ${ }^{4}$ As a result, we need a conscious effort and continuous transfer of knowledge, attitude and behavior in an effort to show the face of Islam that is more accommodating, and not merely purificatory to different cultures, traditions and views of different religions.

In this regard, as an educational institution, basically pesantren has a strategic role in developing the Islamic vision of multicultural education. ${ }^{5}$ This is because in general pesantren grows and develops from the diversity of traditions and local culture. So, growing cultural diversity in pesantren is easily noticeable. This is reflected in the behavior patterns of students of different traditions, humility shown by the kiai, and different cultures, teaching methods, materials, and books that contain various views of scholars that accommodate local traditions. Understanding multiculturalism itself is almost equal to pluralism which is the value system or policy that respects diversity, in a society based on willingness to accept and respect different circumstances of other ethnic, gender or religious groups. ${ }^{6}$

University Press, 2002), p. 72.

${ }^{2}$ Alquran, Surat al Hujarat/49:13: O mankind, indeed We have created you from male and female and made you peoples and tribes that you may know one another. Indeed, the most noble of you in the sight of Allah is the most righteous of you. Indeed, Allah is Knowing and Acquainted.

${ }^{3}$ Roland Robertson, Religion in Sociological Analysis and Interpretation, trans. Fidyani Ahmad Saifuddin, (Jakarta: Rajawali Press, 1988), p. 220..

${ }^{4}$ Hasan Basri, "Multikulturalisme dari Pesantren”, in Ijtihad Pesantren Tentang Toleransi and Good Governance, (Tangerang, Banten, ICIP, 2009).

${ }^{5}$ Multicultural education, according to Bikhu Parekh (2000), serves as "education that liberates various ethnocentric bias and prejudice and explores as well as learns from various perspectives and other cultures. In short, with the introduction of multicultural education, each learner can have a sense of civic culture. Bikhu Parekh, Rethinking Multiculturalism: Cultural Diversity and Political Theory, (Cambridge: Harvard University Press, 2000), p. 225.

${ }^{6}$ M. Syafi'i Anwar:Menggali Kearifan Pesantren untuk Multikultalisme, in Wasathhaniyah, No.1, Februari 2006 M, p.2. 
Pesantren upholds respect regardless of ethnicity and race. The curriculum of pesantren both modern and traditional, teaches students to increase national awareness of the environment and society where people live side by side with various community groups and can spread blessing to the environment. ${ }^{7}$ This is apparently one of the factors that contributes to pesantren being friendly to the environment, in synergy with local cultures, responsive to the new changes that occur in the community, so that pesantren rarely takes violent action against certain groups because they are different. Thus, pesantren education that manages the values of multiculturalism needs to be developed in community life. ${ }^{8}$

Therefore, the existence of pesantren serves as one of the institutions that has a significant role in maintaining local culture, values and harmonious social order. ${ }^{9}$ It is then interesting to examine the extent to which the role of religious education in pesantren in developing multicultural values for students who will take part in a pluralistic society with a Muslim majority.

This research was carried out at Pesantren Sunan Pandanaran Pesantren Muallimin, Yogyakarta. Both pesantrens are seen to have contributed to the world of Islamic education and the birth of cadres and Muslim intellectuals. The selection of the two pesantrens as the object of the study was based on the fact that both schools lay a strong ground for multicultural values in Islamic education in the country. Pesantren in this era of globalization still shows its vitality as a social, cultural and religious force that helps to shape modern Indonesian culture, and this research is intended to find out more clearly the role of religious education in both traditional and modern pesantren. ${ }^{10}$

${ }^{7}$ A. Sholahuddin, Pesantren dan Budaya Damai, http://www.gp-anshor.org/?p+13308, accessed on 1 October 2015.

${ }^{8}$ In Indonesia, some managers of education from elementary to higher education have been introducing multicultural values in their educational curriculum. Multicultural education is seen as a strategic breakthrough for increasing awareness, knowledge and understanding of the people to be tolerant of differences. However, the implementation and management have yet to be well organized. On the other hand there are many parties who do not understand the idea of multiculturalism in their education. For some managers, even the integration of multicultural education in their curriculum seems to be a mere marketing strategy to attract a number of students. In other words, the multicultural educational label is only a discourse but not put into practice in the teaching and learning process and school curriculum. Ridwan al Makassary and soeparto, ed, Multicultural Education Success Story in Indonesia, (Jakarta: Centre for the Study of Religion and Culture (CSRC), 2010), p. xiv.

${ }^{9}$ Nunu Ahmad an-Nahidil, "Pesantren dan Dinamika Pesan Damai" in Edukasi Journal Penelitian Agama dan Keagamaan Vol.4 No. 3, (Jakarta Putlitbang Pendidikan Agama dan Keagamaan, Badan Litbang dan Diklat Departemen Agama RI, 2006), p. 18.

${ }^{10}$ A traditional boarding school or Salaf pesantren is oriented to the preservation of tradition with a traditional education system. 2) modern boarding schools are schools that undergo significant transformation in the education system and institutional elements. This type of pesantren is managed by well organized management, and instruction system im- 
Pesantren Sunan Pandanaran is Nahdliyin-based pesantren which currently has about 2,500 students who come from various regions in Indonesia. In addition to educating the students with the science of religion, pesantren also examines common knowledge by providing formal education from kindergarten to higher education. Although the materials taught include religion and general sciences, Pesantren Sunan Pandanaran still retains the ideology Salaf pesantren in its instruction. Meanwhile, Pesantren Muallimin Muhammadiyah Yogyakarta hereafter referred to as Muallimin is a modern educational institution under the central management of Muhammadiyah organization. This pesantren is no regular school, but it is dubbed the Muhammadiyah cadre school which aims to prepare scholars, teachers, and leaders of Muhammadiyah. In line with the Pesantren Sunan Pandanaran, Muallimin also provides religious and general subjects. In addition, the school is constantly innovating to develop teaching materials by connecting and integrating Islamic studies with the national curriculum, and the Muhammadiyah materials which are related to the "yellow books" or a technique known as the cross curriculum. If the diversity of students of different backgrounds is not managed by observing multicultural values, there is no doubt that the potential to cause conflict is inevitable.

In this light, this research focuses on the role of religious education in pesantren in developing multicultural values, conducted through a case study at Pesantren Sunan Pandanaran and Muallimin Yogyakarta. The analysis of this paper includes the dimensions of knowledge about multicultural values in pesantren, and a practical dimension of the role of pesantren education in developing multicultural values.

\section{PORTRAIT OF MULTICULTURAL VALUES AT PESANTREN SUNAN PANDANARAN AND PESANTREN MUALLIMIN}

\section{Pesantren Sunan Pandanaran}

\section{a. History}

Pondok Pesantren Sunan Pandanaran was founded by KH Mufid Mas`ud on December 20,1975. It began as a boarding school teaching religion in a mosque and a plain home that stood on an endowed land. The name Pesantren Sunan Pandanaran is a way to appreciate the merits of his ancestor, Sunan Pandanaran (Sunan Tembayat) in spreading the teachings of Islam in Central

plemented in equal portions between religious education and general education. See Hasan Basri, "Pesantren Karakterisik dan Unsur- unsur Kelembagaan", in Abu Nata (eds), Sejarah Dan Perkembangan Lembaga- Lembaga Pendidikan Islam di Indonesia, (Jakarta: Grasindo, 2001), p. 124. 
Java. In addition to his being the 12th descendants of Sunan Bayat, KH. Mufid Mas $>$ ud, the founder and caretaker of this pesantren, was originally a counselor of Female Pondok al-Munawwir, Krapyak. Then in October 1975, the scholar who was in Tembayat, Klaten, Central Java moved to the village of Candi Krapyak, Sleman to live on the land of $2000 \mathrm{~m} 2$ endowed by H. Masduqi Abdullah, which is located approximately 200 meters west highway YogyaKaliurang Km.12 Candiwinangun hamlet, Sardonoharjo village, Ngaglik Subdistrict, Sleman Regency Yogyakarta.

At first, the pesantren was intended as a means of propaganda and the education system applied here was recitation of yellow books with wetonan, bandongan and sorogan system as a common practice in Salaf pesantrens, focusing on one area of memorizing the Qurran. Along with its development, later on Pesantren Sunan Pandan Aran managed some religious educational institutions. The educational institutions among others were: Takhassus Tahfidz al-Quran, Radlat al-Athfal (kindergarten), Islamic Elementary School, Islamic Junior high school, Islamic senior high school, and College of Islamic Studies of Sunan Pandanaran, but still retaining reviews of yellow book or books such as Ihya Ulumiddin, Shahih al-Bukhari and Shahih Muslim, Tafsir al-Jalalain, Ta'lim al-Mutaallim, etc. In addition to positioning itself as a religious educational institution, Pesantren Sunan Pandanaran has the vision and responsibility to build character and moral of the community to be more Islamic. In an effort to establish this vision, Pesantren Sunan Pandanaran employs an inclusive approach to the culture of the surrounding communities. In addition to routine activities of reviewing the yellow books conducted by the counselor or teachers with the students, various activities involving the public are also organized by pesantren. These activities include mujahadah, routine recitation of Al-Jauharah, Jamuspa and various economic activities which involve active community participation such as providing foods and drinks for sale at the pesantren, laundry services, supplying water for daily needs, etc. Beside religious and economic activities, Pesantren Sunan Pandanaran also uses art and culture to accommodate various elements of the community of different age and walks of life. For example, the Bedouin dance that grew up in the community is revived and even included in extracurricular programs in the Madrasah. Such approach serves as the basis of various forums that build relations and communication with the community around the pesantren.

Moreover, along with the times, there have been changes in the pesantren itself especially in terms of education and teaching system that originated from Salaf, and viewed from the dynamics now, it can no longer be called the Salaf 
pesantren at all. However, while still maintaining the Salaf education system, as times went by, the pesantren also applied modern educational system. Therefore, for now it is more appropriate to call Pesantren Sunan Pandanaran a mixed or integrated pesantren (between khalaf and the Salaf).

This mixed system can be seen, for example, in the Salaf teaching model with a system of sorogan and bandongan, as well as the tf eaching oyellow books (classical Islamic books). Meanwhile, the khalaf or modern system can be seen in the way the Pesantren applies the classical tiered system, and madrasa education (modern pesantren). Modern education system can also be seen in the adoption of the curriculum prepared by the Ministry of Religious Affairs and combine it with the diniyah pesantren ${ }^{11}$ curriculum.

\section{b. Portrait Multicultural values in Pesantren}

In fact, it is not difficult to find a building with students having a multicultural awareness. The Pesantren diversity in society concerning the language, culture, ethnicity, etc, is an undisputable fact. Thus, the heterogeneity should be an effective tool for a multi-ethnic environment to reject all forms of racism. The values of equality and fairness are in the praxis can be found in students' daily life where everyone has equal rights and responsibilities.

As stated by one of the counselors of Pesantren Sunan Pandanaran:

Daily life at the pesantren is a reflection of a multicultural attitude as it is expected that the students will be ready with a multicultural life out there. Students who study at pesantren come from different regions, and live here with no segregation. Living together in diversity is what creates the look of a new entity in pesantren. ${ }^{12}$

With a wide range of differences, they are required to cooperate with each other and suppress any ego that may arise in their interaction, and these differences should become a motivation to move forward and produce new creation and innovation. As reported by Wardahani, Sri Linggani, Bahtiar and Lutfi:

"The way they learn different dialects from different regions is what forms a new culture of the pesantren. In addition, the tradition of dining together at first when entering pesantren was awkward for some, but soon they get used to it. It is the creativity of studnts at pesantren " .13

\footnotetext{
${ }^{11}$ Interview with Jazilus Sakhok, on 26 October 2015.

${ }^{12}$ Interview with Jazilus Sakhok, on 26 October 2015.

${ }^{13}$ Interview with para students of madrasah Aliyah Sunan Pandanaran, on 03 November 2015 .
} 
Cooperation displayed in the pesantren then demands the same attitude toward the individual. This attitude is regarded as anti-discriminatory and tends to be democratic. These democratic values are practiced in and outside school activities. For example, during the election of Osis administrators, called HTT, students are given equal opportunity to become the administrators through a series of elections, after which candidates will be elected by all students at the madrasa. This process provides a lesson about the values of democracy that provide equal opportunities and treatment of each of the students, so that the results reflect the aspirations of all students. Here are excerpts of an interview with the classroom teacher of the madrasah in charge of student affairs, Teguh Arifiyanto:

In the election OSIS called HTT, it carried out democratically. This is an attitude of respect and appreciation of the differences. In addition to the holding a democratic system in each election, despite the differences between mission and vision of the candidates, it does not cause problems and no conflict arises, they always appreciate the differences. This is very important. ${ }^{14}$

Another important multicultural value shown in Pesantren Sunan Pandanaran is tolerance. Pesantren Sunan Pandanaran seeks to develop values of tolerance and respect through various things including: first, the vision of pesantren leaders about multiculturalism and Pesantren propaganda approach. Second, madrasa activities such as forum of Bahsul Masail, festival/parade of local culture (Merti Dusun, Independence Day). Third, recital of the yellow books in pesantren. Fourth, openness of the pesantren to anyone and any group that wants to get to know the pesantren and Islam in general.

Moreover, Pesantren Sunan Pandanaran is familiar with the programs of cooperation with various external parties related to several issues. Cooperation is essential in building relations with parties outside the pesantren. In an interview Jazilus Sakhok said:

Basically, the counselor does not want any opposition to anyone who comes with good will to this pesantren. This Pesantren is open and we should not close ourselves. We think about how much it hurts those who come to here expecting to cooperate and are rejected. However, we also have to be selective because as we also consider the interests of the students. As long it is beneficial to us and does not interfere with the educational process, we will accept it. ${ }^{15}$

Cooperation built by Pesantren Sunan Pandanaran with outsiders is very diverse. This joint programs are carried out by considering aspects of virtues. With regard to tolerance, there was a cooperation related to the issues of

${ }^{14}$ Interview with Teguh Arifiyanto, on 27 October 2015.

${ }^{15}$ Interview with Jazilus Sakhok, on 5 December 2015. 
multiculturalism in pesantren, i.e. cooperation with the CSRC (Center for the Study of Religion and Culture) of Syarif Hidayatullah State Islamic University Jakarta under the "Pesantren for Peace" program. ${ }^{16}$ The emphasis of cooperation on the program of "Pesantren For Peace" is an attempt to align Human Rights which are strongly emphasized in the Western world with a unique culture and religious principles of Islam in Indonesia. In other words, the core of this cooperation includes supporting the principles of democracy, human rights, religious tolerance, the principles of a constitutional state, as well as gender equality in the midst of the Indonesian Islamic community. ${ }^{17}$

Matrix 1. Multicultural values in Pesantren Sunan Pandanaran

\begin{tabular}{|c|c|c|}
\hline No & Multicultural Value & Description \\
\hline 1 & Living with others & $\begin{array}{l}\text { Diversity is reflected in the daily life of students. } \\
\text { It is expressed in two ways; first, the culture that } \\
\text { developed in pesantren which is in fact diverse. } \\
\text { Students coming from various regions bring vari- } \\
\text { ous cultural pattern, thus requiring them to accept } \\
\text { each other and learn to respect differences. Second, } \\
\text { the yellow books are used as reference for review- } \\
\text { ing the field of science in pesantren. }\end{array}$ \\
\hline 2 & Equality and justice & $\begin{array}{l}\text { Each student has equal rights and responsibilities } \\
\text { without distinction of regional, ethnic and social } \\
\text { origins, e.g. bathroom and bedrooms facilities are } \\
\text { the same for all students. }\end{array}$ \\
\hline 3 & $\begin{array}{l}\text { Brotherhood and } \\
\text { helping each other }\end{array}$ & $\begin{array}{l}\text { The emergence of a sense of brotherhood and } \\
\text { mutual help is guided by several reasons, first the } \\
\text { similarities of fate/state that they are away from } \\
\text { their family and common purpose of studying re- } \\
\text { ligion and other general subjects at the pesantren, } \\
\text { as well as the emergence of communal identities } \\
\text { as the pesantren community. These values are also } \\
\text { built through a method of learning by doing. }\end{array}$ \\
\hline
\end{tabular}

${ }^{16}$ Related to this cooperation, Pesantren Sunan Pandanaran becomes one of the local partners of CSRC in the Yogyakarta area. In his statement Hemay Idris said: We are working with five schools in the Java area related to the Pesantren for Peace program. The distribution is complete in each area in 5 provinces. Boarding schools in East Java: al-Hikmah in Surabaya; West Java: Pesantren Babus Salam in Bandung Regency; Central Java: Edi Mancoro Salatiga, and in Yogyakarta : Pesantren Sunan Pandanaran. Selection of boarding schools is determined by two factors: first, the relationship and the willingness of the pesantrens. We observed some schools that do not have the negative stigma associated with western terms such as human rights, etc. Telephone Interview with Idris Hemay on 26 December 2015

${ }^{17}$ Interview with Jazilus Sakhok on 27 December 2015. 


\begin{tabular}{ll}
\hline Democracy & $\begin{array}{l}\text { The practice of democratic values at the Pesantren } \\
\text { Sunan Pandanaran can be seen in the aspect of ed- } \\
\text { ucation and teaching such as teacher recruitment, } \\
\text { teaching methods, and activities in the madrasah. }\end{array}$ \\
& Establishing the values of tolerance and respect \\
through various things including: first, the vision \\
of pesantren leaders on multiculturalism and pro- \\
paganda approach; second, madrasa activities such \\
as forum of Bahsul Masail, festival / parade of local \\
culture (Merti Dusun, Independence Day); and \\
third, recital of yellow booka, and fourth, openness \\
of pesantren to anyone and any group that wants to \\
get to know the pesantren and Islam in general.
\end{tabular}

\section{Pesantren Muallimin Yogyakarta}

\section{a. History}

Pesantren Muallimin Muhammadiyah is a school of union cadres that prepares future Muhammadiyah leaders. Muallimin is a pesantren based school. This school was founded by K.H. Ahmad Dahlan in 1920 under the name "Qism alArqam" or often called the "Hogere School" which means Higher Secondary School. At the time, the place for instruction was the dining room which was also Ahmad Dahlan's family kitchen. In 1923 the name was changed to "Kweekshool Islam", and then changed to "Kweekschool Muhammadiyah". It was a mixed gender school. In 1927, separation of female and male students was made by establishing "Kweekschool Wife". Finally in 1930, the Muhammadiyah congress in Yogyakarta decided that both teacher training schools were renamed "Madrasah Mu'allimin Mu'allimat". Then, in 1928, the Congress in Medan gave a mandate to the Muhammadiyah Central Executive to formally manage Madrasah Mu'allimin Muhammadiyah Yogyakarta as education center for cadres of leaders, religious teachers and preachers of Muhammadiyah. ${ }^{18}$

Historically, Muallimin went through several changes in its educational

${ }^{18}$ Austin Wahyuningsih, Managemen Pendidikan Karakter (Lombok: Elhikam Press, 2015), p. 90. 
system. At first, the maskan (dormitory) was separated the madrasah system, but since 1980, Muallimin began to adopt a system of "long life education". In this system, the dormitory and madrasah form an inseparable institution. This step was based on the theory that the purpose of education, according to the Muallimin idealism, can only be achieved by combining the madrasah system and the dormitory. Another crucial change was also made in 1987 especially related to a new curriculum system. The goal is to make teaching process more effective and efficient. This policy was continued by designing the concept of integrating the curriculum of Islamic and Muhammadiyah materials known as a Crossing Curriculum system, which basically integrated the curriculum materials of Islamic high school prepared by the Ministry of Religious Affairs with Muallimin material that refer to the yellow books. This process continues to grow until today, of course, to achieve ideal results, evaluation and continuous revision have been made to Islamic and Muhammadiyah materials.

As a Muhammadiyah educational institution, Mu'allimin has a vision to prepare cadres, scholars, leaders and educators to carry out the missions of Muhammadiyah movement. In the characteristic aspects of education, Muallimin as a school of Muhammadiyah cadres has also changed. During the Dutch and Japanese colonial periods, mandatory education was 5 years, but starting in the academic year of 1957/1958, mandatory education at Muallimin was 6 years --comparable to PGAA / PGAN-- and the time span has survived until today. In the colonial period and two decades after independence, Muallimin became a model of militant Muhammadiyah cadres. The term "the Arrows Muhammadiyah" was a pride for the alumni who dedicated themselves to be sent to various parts of Indonesia. There, they carried out self-actualization as a cadre of Muhammadiyah, and as a result, the establishment of new branches of Muhammadiyah or the birth of new madrasah that were modeled after Mu'alimin Muhammadiyah Yogyakarta. ${ }^{19}$

\section{b. Portrait of Multicultural values in Pesantren}

In a sense of being a wealth of ethnicity and culture, multiculturalism is a tangible reality at Pesantren Muallimin Yogyakarta. There are at least two aspects that can be seen as an objective reality in a multicultural life there. First, the human resources aspect. In this aspect, the students studying in the pesantren come from a wide variety of customs, traditions, culture, and languages. It is inseparable from the fact that these students come from

${ }^{19}$ Student Development Guide Book, Madrasah Mu'allimin Muhammadiyah Yogyakarta, 2012, p. 3-9. 
various regions in Indonesia which is a country with different cultures and diverse population groups. The fact is confirmed by Asep Sholahuddin as the counselor and director of the madrasah as follows:

"The Pesantren had existed long before Indonesia's independence. The main purpose was to prepare cadres, scholars, educators and leaders. The ideals are continued to be advocated and socialized until today. The Pesantren can be called a miniature of Indonesia. Until now, students who study at the pesantren come from various ethnic groups in the country. They come not only from Java, but also from Sulawesi, Kalimantan, Sumatra, as well as some other areas. This is a gift for us as the managers, and a challenge that we must face. " 20

The diversity of cultural backgrounds is in fact not only common among the students but also among the teachers (in the context of pesantren known as ustadz). In addition to coming from various regions, the teachers can be divided into two categories; those who graduated from Muallimin Yogyakarta and non-alumni. The difference of background reflects the multiculturalism and the wealth of Muallimin pesantren.

The second aspect is the diversity of students' organizations (Organtri). A wide range of students' organizations that deal with art, sports, journalism can be found here, and they create tendencies and diverse culture at the level of students. It is this diversity which then forms characters that vary among students. As reported by one of the students:

'Students' Organizations in this pesantren are quite diverse. Organtri plays a role in shaping the character and leadership of the students. Sometimes there is a sort of competition with each other even some occasional friction. Students with in a particular organization flock together, while others gather in their respective groups. But this friction does not lead to a prolonged conflict. It's only a matter of competition indeed. ${ }^{21}$

In response to the multicultural reality, the key principles that must be held by the academic community of Pesantren Muallimin are fraternity and egalitarianism. The attitudes are practiced as a single family, and egalitarianism is not only common among the students or teachers, but also between students and teachers. Ruslan Fariadi reported:

"When outsiders look at Pesantren Muallimin in a glance, they might assume that students here lack the ethics (impolite). This is because the relationship between students and teachers is egalitarian. Some people who are new to the

${ }^{20}$ Interview with Asep Sholahuddin on 12 October 2015.

${ }^{21}$ Interview with Ramzi dkk on 19 October 2015. 
neighborhood will immediately be surprised to see it. It is because basically we want the students to be critical and not dogmatic. "22

Such multicultural atmosphere in the pesantren as described above is actually a quite encouraging phenomenon. The absence of discrimination in this pesantren, both structural and non-structural, indicates that this place is reliable in understanding and addressing the existing diversity. However, as implied from the statement of Asep Sholahuddin earlier, the real challenge is the management and strategy in utilizing the diversity of cultural backgrounds. In addition to preserving and living with diversity, of course the pesantren has noble ideals to prepare cadres. ${ }^{23}$ Therefore, the application of multicultural values is necessary, but on the other hand, Muhammadiyah values are also important to instill. In order to prepare future cadres, cultural diversity is a real challenge in the process of education and instruction in pesantren.

The principles of diversity embedded in the consciousness of the students of Pesantren Muallimin Muhammadiyah Yogyakarta did not "suddenly" appear. It is an attitude that is continuously encouraged. First-hand experience by the students is very helpful in the process of increasing this awareness. In addition to culture-related issues, tolerant attitude based on the principles of diversity also concerns the attitude toward other religions. Misbahul Munir stated in an interview:

"Our attitude and that of our students is tolerant of other religions. "Our neighbors are people of other faiths. Our students often see "budhen". Every morning in front of this Madrasah, they can see people doing rituals. Behind the school, there is also a Catholic Church, the students are reasonable and tolerant in their view and reaction to it. We have always taught that the Prophet was not arrogant to non-Muslims. ${ }^{\text {"n }}$

Another objective condition very positive in the face of the multicultural reality is good relations promoted by the pesantren. The program to improve relations with the community is the responsibility of the Assistant Director for Public Relations. There are two elements targeted in the program, the guardians of students and the surrounding community members. The counselors are aware of the importance of good relations with the public. Moreover, the dynamics of

${ }^{22}$ Interview with Ruslan Fariadi on 30 October 2015.

${ }^{23}$ Simple definition of a cadre is a group of people organized in a continuous basis and will become the backbone for a larger group. Imron Nasri (ed), Pluralisme dan Liberalisme; Pergolakan Pemikiran Anak Muda Muhammmadiyah (Yogyakarta: Citra Karsa Mandiri, 2005), p. 96. In this sense, it is understood that as a cadre school, Pesantren Muallimin Muhammadiyah Yogyakarta wants to prepare cadres of scholars, leaders, and educators who will become the backbone and driving force of the entire Persyarikatan Muhammadiyah.

${ }^{24}$ Interview with Misbahul Munir on 12 October 2015. 
the community are very influential to the relations. In fact, today the relations between the pesantren and the community tend to be getting better. In an interview it was stated that:

So far, All Praises be to Allah, relations between the pesantren and the community are good. It is in fact getting better and better. In the past, we had some misunderstanding with the community around us, but All praises be to Allah, not anymore now. We usually allocate funds for community-related activities. It is the duty of the Public Relations to instill multicultural values, one of which is through the program of "Harmonization of public relations". We actively participate in the neighborhood association in the form of social fund or personnel. We are also working with the community to monitor the students. ${ }^{25}$

This good relationship promoted by the pesantren with its surrounding community is also carried out by students' guardians. The Pesantren always sends a representative for funeral of the students' family members. In fact, according to Teguh, the pesantren never hesitates to send a representative even to places outside Java. ${ }^{26}$ This relationship is an awareness built by Pesantren Muallimin.

Moreover, social awareness as a continued effort in developing relations with the community is achieved with useful programs. These programs are usually planned every year with a needs analysis. The Head of public relations of Pesantren Muallimin stated:

"Community programs that can be felt immediately and have wider benefits, we usually distribute sacrificial meat and other charity activities. This year, we held it in Gunung Kidul by distributing basic food and water supply. This is part of our effort to help our brothers and sisters in need of water. On the other hand, this is also a way of educating students to perform managerial tasks related to social service as well as growing and developing a sense of social awareness. ${ }^{27}$

\footnotetext{
${ }^{25}$ Interview with Teguh on 30 October 2015.

${ }^{26}$ Interview with Teguh on 30 October 2015.

${ }^{27}$ Interview with Teguh on 30 October 2015.
} 
Matrix 2. The values of multicultural Pesantren Muallimin

\begin{tabular}{|c|c|c|}
\hline No & $\begin{array}{c}\text { Multicultural } \\
\text { values in Pesantren }\end{array}$ & Description \\
\hline 1 & Diversity & $\begin{array}{l}\text { Both students and teachers come from various } \\
\text { ethnic, cultural, racial, and language back- } \\
\text { grounds. In addition to a reality of life, diver- } \\
\text { sity is recognized and understood positively in } \\
\text { pesantren }\end{array}$ \\
\hline 2 & Democracy & $\begin{array}{l}\text { Pesantren does not treat the differences in a } \\
\text { discriminatory manner, be it structurally and } \\
\text { non-structurally. All teachers and students } \\
\text { have equal opportunities in presenting their } \\
\text { opinions and ideas. }\end{array}$ \\
\hline 3 & Egalitarianism & $\begin{array}{l}\text { Good relationship maintained between the } \\
\text { teacher and students are based on their status. } \\
\text { Students at the pesantren receive equal treat- } \\
\text { ment. }\end{array}$ \\
\hline 4 & Tolerance & $\begin{array}{l}\text { Appreciate and accept religious differences } \\
\text { around the pesantren. Students and teachers } \\
\text { are not allowed commit any acts that disturb } \\
\text { the worship of the Buddhists and Christians } \\
\text { who live around the pesantren }\end{array}$ \\
\hline 5 & Social awareness & $\begin{array}{l}\text { The Pesantren establishes good relations with } \\
\text { the communities around it, guardians of } \\
\text { students and society at large. The good rela- } \\
\text { tions are based on a sense of social awareness. } \\
\text { Programs that can be felt directly by the people } \\
\text { such as social service and distribution of clean } \\
\text { water become a priority. }\end{array}$ \\
\hline
\end{tabular}

\section{THE ROLE OF EDUCATION AT PESANTREN SUNAN PANDANARAN AND PESANTREN MUALLIMIN IN DEVELOPING MULTICULTURAL VALUES}

Based on the observations and interviews conducted, the researcher found that the pesantren education has a significant role in the development of multicultural values both at Sunan Pandanaran and Muallimin Yogyakarta. In general, there are several similar factors that contribute to the values in the context of the role of secondary education of pesantren. However, differences. 
At Sunan Pandanaran, there are four major factors that play an important role in the development of multicultural values. First, the recitation the yellow books. Related to the books used, pesantren Sunan Pandanaran applies the tradition yellow book reviews as an educational resource. The term yellow book itself is no stranger among pesantrens, especially the traditional ones. Martin Van Bruinessen in his research mentioned that the yellow book is a characteristic in a traditional pesantren that is not present in a modern. In a multicultural context, it is understood that the method of recitation of yellow books taught using the Javanese language as the language of instruction is a way to appreciate local culture, and is a form of local wisdom. On the other hand, it would be very difficult for learners or students who come from outside Java which seems to give the impression of discrimination in education. In response to the issue it was stated that:

But this does not mean discrimination to the non Javanese students, as in teaching or in the selection process there is flexibility. Gradually it will be taught to non Javanese students. After all, the Javanese language is the language of instruction. Suppose a student does not understand pegon, we will teach him slowly until he understands. We are not going to push him, but slowly teaching him. We place them in classes according to their ability. It happens to be $95 \%$ of the students of Madrasah come from Java, so that only 5\% who need special assistance in the face of difficulty of learning the books written in the Javanese language. The book Ta'lim al-Muta'alim is taught to strengthen the character of the students. So how to behave as a teacher, and as a student. There is continuity. Just listening as parents teach their students . Ultimately, it will affect the students 's behavior. ${ }^{28}$

Second, the notion of pesantren being inclusive and tolerant that develops in pesantren in addition to the principle of dialog, also includes rejecting prejudice. In pesantren, students are taught to respect differences. Tasamuh or tolerance relies on the attitude of being good, gentle, and forgiving each other. In a general sense, tasamuh is the attitude human relationship, i.e. there is mutual respect between them within the limits outlined in the Islamic teachings. That is one of the main characteristics of the traditions developing in the pesantren. This tasamuh attitude goes hand in hand with everyday life. This notion of inclusiveness is also observed by teachers of Madrasah Aliyah Sunan Pandanaran, as expressed by Zulfa ${ }^{29}$, one of the teachers at the madrasah:

Long before the UN Declaration of Human Rights, Islam had taught the

${ }^{28}$ Interview with Ainun Hakemah on 27 October 2015

${ }^{29}$ Interview with Zulfa, on 30 October 2015 
freedom of religion through the «Charter of Medina` in $622 \mathrm{AD}$. In the Charter of Medina, Prophet Muhammad (pbuh) laid the cornerstones for the diversity of life among people of different religions, as well as acknowledge the existence of non-Muslims and to respect their worship.

Third, pesantren' multicultural curriculum. This multicultural education curriculum is not directly written in the structure of the curriculum but its values are applied. Indication of the application of such hidden curriculum can be seen in the way pesantren develops a spirit of brotherhood, cooperation (tarawun), tolerance (tasamuh) and appreciation. So, education in fact teaches students not only to have knowledge (learning to know) or prepare a generation that has skills and specific characters (learning to be), but also should teach about how to behave, and interact with others by appreciating the differences between them as something that enriches (learning to work and live with). In other words, education is the process of humanization. Education is not just a process of helping students to become good citizens, but at the same time also to become humans integrated with intellectuality, morality, capacity and sensitivity, as well as to be comfortable with differences. Ainun Hakiemah further confirmed that the existence of multicultural education as a hidden curriculum at Pesantren Sunan Pandanaran, its implementation, and the importance of examples and exemplary attitude of the teachers toward multicultural value will emulated by the students. It was stated in the following interview:

Structurally, multicultural education curriculum is difficult, so it is indeed [easier] with hidden curriculum. Nguwongke Uwong is also there. When teachers feel convenient in their office room, it means they already have nguwongke uwong, humanism. The administration staff for example were once our students. But now they are equal to us, they are not allowed to scold someone in front of students. Once there was [a staff] doing it, it's not ethical, then we recalled this person. It was awful because it [reflects] the values or our attitude toward something. ${ }^{30}$

Fourth, the teacher's role in developing multicultural values. At least, there are two main roles that teachers play in developing multicultural values, i.e. insight and understanding of multiculturalism and instructional methods. According to the Headmaster of Islamic senior high school, Ainun Hakiemah, variations of teaching methods is often applied at the school such as discussion, group work and collaborative learning.

Many subjects are delivered through the methods of discussion, group work, so as to accept the opinion of others. It is common for students to

\footnotetext{
${ }^{30}$ Interview with Ainun Hakiemah on 27 October 2015.
} 
have a conversation with and send messages to the teachers. There is also an extracurricular activity called Ba'tsul Masail attended by first and second year students, a lot of discussions about various issues, each receiving the opinion of the other, no violence, and this certainly teachers tolerant attitude among the students. ${ }^{31}$

With regard to the above variations in learning, teachers at the madrasah Aliyah Sunan Pandanaran applied a learner-centered approach. This approach enables students to play an active role, while the teacher serves as a facilitator. One of the variations of the learner-centered approach is the "collaborative learning". Collaborative learning is a learning process where each member of the group contributes ideas, information, news, attitudes, opinions, skills to improve all members' understanding.

Matrix 3. Educational Role of Pesantren Sunan Pandanaran in Developing Multicultural Values

\begin{tabular}{ll}
\hline No $\quad$ Factor & \multicolumn{1}{c}{ Description } \\
\hline Tradition of yellow book & $\begin{array}{l}\text { Diversity materials contained in the } \\
\text { yellow book enable students to have a } \\
\text { view and deal with differences in the } \\
\text { community. }\end{array}$ \\
\hline Inclusive Religious view & $\begin{array}{l}\text { This view is characterized by dialog } \\
\text { and cooperation and humanitarian- } \\
\text { ism. As a realization of such religious } \\
\text { concept, Pesantren Sunan Pandanaran } \\
\text { accommodates diversity among stu- } \\
\text { dents and teachers to coexist there, } \\
\text { open to all who want to visit, get to } \\
\text { know the pesantren and Islam as well } \\
\text { as to play an active role in supporting } \\
\text { programs of cooperation with other } \\
\text { parties to build peace or known as } \\
\text { "Pesantren for peace" program }\end{array}$ \\
\hline &
\end{tabular}

\footnotetext{
${ }^{31}$ Interview with Ainun Hakiemah, on 27 October 2015.
} 
Moderate curriculum is characterized by the dominance collection of books by scholars of peace such as Imam

Curriculum with moderate

3 and multicultural perspective Shafi'i, Imam Ghozali, etc., as references in book reviews. IN addition, the culture of discussion, debate and intellectual competition has become the practice of pesantren education. This teaches students about the values appreciating the opinions of others.

There are two roles of teachers: first, the insight and understanding of teachers on multiculturalism. Thus, teachers at Sunan Pandanaran pesantren embrace diversity and realize that multiculturalism is derived from the teachings of Islam

As for education at Pesantren Muallimin there are three main factors that play an active role in the development of multicultural values: First, an inclusive, critical culture and dialog. ${ }^{32}$ Being open to understand, learn, express opinions is encouraged by the teachers and the counselors. The involvement of the counselors and the teachers in building an inclusive culture is manifested either in the classroom or outside. This is a critical teaching method in addition to the way students explore by themselves. Ruslan stated:

"Since the beginning we tell our students "it should not be taboo to disagree even with their own teachers. However, opinions should be delivered in an ethical way. There are several strategies related to enrichment and absorption of materials. First, top down, we explain directly. Second, arisan system, they choose the theme of the discussion and then give a present it. This is where the values of multiculturalism seem right, since Muallimin is a miniature of Indonesia. Those with different characters blend together." ${ }^{\text {33 }}$

Second, the factor of books used in education at the pesantren. At Pesantren Muallimin Muhammadiyah, there are two categories of books used: textbooks and instructional books. Both categories of books were created and carefully

${ }^{32}$ Inclusive culture requires an attitude of tolerance towards others. The main principle in this culture is that even though we are different, we actually have things in common and this similarity must continue to be our principle. Thus, an open attitude is not only a choice but also a necessity. Zakiyuddin Baidhawy, "Pendidikan Agama Berwawasan Multikultural", Jurnal Tashwirul Afkar, XVI edition (Jakarta: Lakpesdam NU, 2004), p. 141.

${ }^{33}$ Interview with Ruslan Fariadi on 30 October 2015. 
formulated by a team of experts in the leadership rank. These books support and determine the direction or orientation of pesantren education. Therefore, Pesantren Muallimin Muhammadiyah does simply use a textbook formulated by the Ministry of Religious Affairs. Ruslan explained:

"Related to the insight of differences or multiculturalism, I can assure that if you just look at the structure of the curriculum and the syllabus, it will not provide a full picture because the development is seen in the instructional materials. Books are solely used as a reference for our later modifications. We accustom the students to different opinions." ${ }^{\text {34 }}$

Various books are a decisive factor in the cultivation of the values of multiculturalism in this pesantren. However, we need to sort out some books that can be counter-productive. Realizing this, Misbah explained:

"We do not turn a blind eye to various books. There are some that may potentially create fundamental attitude and there are some that seem to be liberal. Therefore, we use the moderate ones, neither right nor left. Books are selected and created by a team to fit the vision and mission of the pesantren. In the Marhad, the tafsir book that we use is the one by Yunahar Ilyas (neither right nor left). For hadith, we use Hadis Miah, Bulughul Marom and Riyadhus Sholihin. The main theme in these books is related to muamalat and morality. Selection of the books is in accordance with the vision and mission of the pesantren cadres. The goal is that it will not become public scrutiny if there are practices not in accordance with the appropriate methodology of the cadre ${ }^{35}$ school

Meanwhile the third factor, the priority programs of the pesantren. In addition to teaching and learning activities carried out on a daily basis at the madarasah or pesantren, there are several programs deemed significant and are a form of actualization of efforts to increase insight into multicultural values. There are at least two featured programs organized by the pesantren to support the vision of multicultural education.

\section{a. Tamhidy program}

Tamhidy is a program devoted to the first year students. Its lasts for approximately 20 days. The main objective is to provide a fundamental understanding of life in the dormitory or Marhad. Students have been reminded that despite the fact they come from different backgrounds, regions, families, even traditions, in the life of pesantren they are equal in a big family

\footnotetext{
${ }^{34}$ Interview with Ruslan Fariadi on 30 October 2015.

${ }^{35}$ Interview with Misbahul Munir on 12 October 2015.
} 
of Pesantren Muallimin Muhammadiyah Yogyakarta. ${ }^{36}$

In practice, there are four important processes related to the orientation Tamhidy program: (1) Conducting the process of "zero mind". The target of this activity is that each student in the Madrasah should have an "intention" / a starting point to move from there to complete the main task for six years at the Madrasah Murallimin Muhammadiyah Yogyakarta. (2) Conducting the process of "internalization". Students have full awareness that they are living amid those who are different, so it is absolutely necessary to have attitude of "tasamuh", develop the "Muslim brotherhood" and the need for collaboration in their daily life. (3) Conducting the process of "integration". Students can practice the values / theories obtained through various methods in daily life (Quran recital, Arabic / English, practical worship, daily prayer). (4) Conducting the process of "habituation" with the aim of making the studentss behavior which is the results of integration (morality) a habit in their life, outside the Maskan and wherever they are. ${ }^{37}$

\section{b. Mubaligh Hijrah Program}

This is a featured program at this pesantren. The program is always mentioned and explained by any informant encountered. The mention of Mubaligh Hijra refers to the concept of the program where students conduct community service. To be more precise, the concept of the program is illustrated by Asep Sholahuddin as follows:

"In practice, every Ramadan students of class IV and V have Mubaligh Hijrah program held for 20 days. The program is organized in cooperation with the Muhammadiyah central executive team. Students conduct community service assisted by tutors. During this time, the program is running well in and outside Yogyakarta. They independently manage and organize various things related events or activities carries out. ${ }^{38}$

Regarding multiculturalism, at least there are two advantages of this program:

\footnotetext{
${ }^{36}$ According to the information obtained, Tamhidy program is not the same as students' orientation activities. This program is more intensive and the students gather every day in accordance with the specified classes. While the orientation of students put more effort to socialize the activities of Islamic school in general, the accentuation program of Tamhidi stresses on ta'aruf and habituation of living in a dormitory. This is a very important program for supporting the students to be able to concentrate on further education in madrasah and $M a$ 'had. Hopefully, they are no longer bothered by problems related to life in the dormitory. Differences are expected to be addressed accordingly. Extracted from interviews with Asep Sholahuddin and Misbahul Munir on 12/10/2015.

${ }^{37}$ Draft Document of Tamhidy concept class I and IV Madrasah Muallimin Muhammadiyah Yogyakarta T.A. 2012/2013. P. 4.

${ }^{38}$ Interview with Asep Sholahuddin on 12 October 2015.
} 
First, students have the opportunity to learn from the community about the diverse reality of life. By interacting directly with different walks of life, the students are expected to broaden their horizon, especially related problems faced by the community. Second, students have the opportunity to socialize while providing views related to religious issues. By following the principles of the Muhammadiyah methodology, diversity in the understanding of religion is very open because it is not confined to certain school of thought.

Matrix 4. The role of education in improving multicultural values at the Pesantren Muallimin

\begin{tabular}{l} 
Pesantren education in improving multicultural values \\
\hline No $\quad$ Factor $\quad$ Description
\end{tabular}

Students are taught to get accustomed to different opinions

Students are given the opportunity to gain knowledge independently

Inclusive, Critical

1 Culture and Dialog

Careful and critical attitude is taught to understand different opinions

Students do not hesitate to ask a variety of questions. In fact, they are taught to get used to asking questions and hold dialog on issues of daily problems, for example. 
Textbooks used in Madrasah is a modified version of Ministry of Religious Affairs. The goal is to have more different perspectives and not stuck on the main2

Books stream perception.

Teaching materials used in pesantren have been carefully selected. Only moderate books are used.

Pesantren Featured programs
Tamhidy program; Habituation program for new students. This program is intended not only to introduce the activities at the pesantren, but also an effort to provide an understanding of the differences and how to deal with them.

Mubaligh Hijrah Program; the pesantren gives an opportunity for the students to learn firsthand experience from society.

\section{OBSTACLES IN THE DEVELOPMENT OF MULTICULTURAL VALUES}

Competence of the teachers or educators in delivering the materials and educating students has an important position in the educational context of multiculturalism. These teachers are required to have a quite broad knowledge in order to provide a good understanding associated with diversity and differences despite todays educational model having been oriented toward learners. However, the role of teachers is significant in the education of multicultural values. Should they have insufficient ability and insight on multiculturalism, these teachers will only become an obstacle in successful development of these values.

At the Pesantren Sunan Pandanaran, even though the investigation showed that the teachers generally had quite inclusive and moderate religious views, in practice, some teachers are less democratic. It was reported by some students in the following interview:

"Once there was a teacher who had discriminatory attitude, paying more 
attention to smart students. Questions asked by students who are less intelligent were ignored, so it s not fair I think."

"The Qur'an teacher, too, often said we were wrong when there was a question, in contrast to what had been described. I often translated by myself, then asked questions. Actually, the teacher knows what is being explained but he teaches in accordance with the meaning written in the book."

"Sometimes teachers also often forget. They forget that they are teaching students who are also santri. There are teachers from outside of the pesantren who often gives a lot of homework, thus putting a lot of pressure on the students. They don't know what it feels to be at the pesantren. Teachers like to forget the conditions of the students. We have to arrange time between the activities of the school and pesantren. In addition, they create new rules. We should be prompt. We deserve equal treatment, not just those deemed more diligent." ${ }^{39}$

These facts show the real urgency of the teacherss role as someone who act in a democratic manner, displaying good behavior or attitude that is not discriminatory, having broad knowledge and high sensitivity of the events related to religion, is strictly emphasized in the Pesantren Sunan Pandanaran. Similarly, this is also the case at the Pesantren Muallimin. It was found that although most teachers delivered materials and religious subjects from different perspectives, some of them simply do it from one perspective only, for example from the Muhammadiyah manhaj perspective. One of the students stated:

"We are accustomed to the differences of opinion delivered by the teachers. However, there are also some religious teachers who directly give a certain opinion without other perspective about the law or the issues. They usually teach one opinion and deliver it without comparing with other opinions." 40

Issues related to competence was also admitted by the teachers. Life experience and varied educational backgrounds are said to be the dominant factor. Lathif Rifa $>$ explained:

"Personally, I have an advantage because once I lived among the Nahdhiyyin with very different traditions. Four years of living in the pesantren Krapyak. But some teachers have different experience. Therefore, it is possible that the values of diversity are not delivered properly to the students. To me, experience

${ }^{39}$ Interview with students at M.A. Sunan Pandanran Wardahani, Sri Linggani, Bahtiar and M Lutfi, on 03 November 2015.

${ }^{40}$ Interview with Ramzi dkk on 19 October 2015. 
is an important for a teacher's competence" ${ }^{\text {"41 }}$

Another obstacle found in pesantren education in terms of developing the values of multiculturalism is the dilemma of identity. Multicultural education on the other hand is feared to obscure cultural identity of the students. Therefore, although different views are taught, students must eventually be led to a single model of understanding, thinking patterns and certain religious practices. Ruslan Fariadi stated:

"Other traditions are still taught, but students remain convinced of the teachings of the Qurran and Sunnah. Questions and discussions related to other traditions are heard and then taught and understood with appropriate guidance. In this case, knowledge and cognitive abilities are important to them, so knowledge of the disagreements related to prayer, for example, is always discussed. In practice, however, we only use the methodology of the Tarjih Muhammadiyah." ${ }^{42}$

Fear of identity obscurity and lack of clear positions related to multiculturalism were implicitly explained by pesantren counselors. Asep Sholahuddin said: "We teach different views, but we must have a standpoint. [We] Appreciate the differences due to different methods and we have a particular method as well." ${ }^{\prime 3}$ There is a very clear impression if a multicultural perspective assumes unclear stance on the identity, subsequently it will deny the community identity. In the context of the dilemma, the establishment of community identity and culture by strengthening the methodology of Muhammadiyah becomes important. Such dilemma of identity is more obvious in the pesantren education in Muallimin compared to the Pesantren Sunan Pandanaran. In the context of the vision and mission, it is quite understandable since Muallimin is regarded as as pesantren of cadres.

Basically, the actual values of multicultural identity do not want vagueness as feared. Openness and recognition of diversity further necessitates the power of identity and of the existing cultural community. Therefore, cadre education reinforced by establishing cultural identity is not against the multiculturalismbased pesantren education. Instead, both are consequences that go hand in hand. That is, the education of cadres run as intended and at the same time the education and cultivation of the values of diversity persist. However, it is important to think about is the strategy on the balance between the two. Too much focus on educating diversity and ignoring educating the cadres is a big mistake because in addition to the fact that it is against the vision and

\footnotetext{
${ }^{41}$ Interview with Lathif Rifa'i on 31 October 2015.

${ }^{42}$ Interview with Ruslan Fariadi on 30 October 2015.

${ }^{43}$ Interview with Asep Sholahuddin on 12 October 2015.
} 
mission of the establishment of pesantren, it is also an event that is not desired by the principle of multiculturalism itself. Instead, educating the students with a perspective and methodology of Muhammadiyah only by ignoring the education of diversity in a multicultural society will produce a cadre who does not understand the reality.

\section{CONCLUSION}

In light of the discussion, it can be concluded that: first, multicultural values seem to be reflected and has become a good principle at Pesantren Muallimin and Sunan Pandanaran Yogyakarta, despite the different characteristics. At the Pesantren Sunan Pandanaran, the values of multiculturalism include: living with others, equality and justice brotherhood and solidarity, democracy, tolerance and cooperation. Meanwhile at Muallimin, there are similar values practices, such as: diversity, democracy, egalitarianism, tolerance, and social responsibility. Those values are firmly rooted in the pesantren and have become a principle in the pesantren's life. The second conclusion is education at both Sunan Pandanaran and Muallimin Yogyakarta has an important contribution to the development of multicultural values, each with different traits and characteristics. While the role of pesantren education at Sunan Pandanaran in developing the values of multiculturalism lies in the cultural aspects, such as inclusive views, yellow books, and the teachers' role, in contrast, Pesantren Muallimin Yogyakarta build those values through programs such as Tamhidy and muballigh hijrah.

The difficulties faced by the two pesantren include uneven competence and knowledge of the teachers in promoting multicultural values in education. Intolerance to differences can still be seen even though the extent is not alarming. In addition, there appears to be a dilemma between maintaining self-identity, teaching or reinforcing a particular tradition, and providing different views. Therefore, efforts to hold dialog and outreach related to multiculturalism comprehensively to accommodate the strongly established traditions in pesantren.

\section{REFERENCES}

Al-Makassary, Ridwan dan Suparto ed. Cerita Sukses Pendidikan Multikultur di Indonesia. Jakarta: Centre for the Study of Religion and Culture (CSRC), 2010.

an-Nahidil, Nunu Ahmad. "Pesantren dan Dinamika Pesan Damai" dalam 
Edukasi Journal Penelitian Agama dan Keagamaan Jakarta Putlitbang Pendidikan Agama dan Keagamaan, Badan Litbang dan Diklat Departemen Agama RI, 2006. Vol.4 Nom. 3.

Anwar, M. Syafi'i. "Menggali Kearifan Pesantren untuk Multikultalisme”. dalam jurnal Wasathhaniyah. No.1, Februari 2006.

Baidhawy, Zakiyuddin. "Pendidikan Agama Berwawasan Multikultural”, Jurnal Tashwirul Afkar. Jakarta: Lakpesdam NU, 2004. Edisi XVI.

Basri, Hasan. “Multikulturalisme dari Pesantren”, Dalam buku Ijtihad Pesantren Tentang Toleransi dan Good Governance. Tangerang, Banten,ICIP, 2009.

Basri, Hasan. "Pesantren Karakterisik dan Unsur- unsur Kelembagaan", dalam Abu Nata (eds). Sejarah Dan Perkembangan Lembaga- Lembaga Pendidikan Islam di Indonesia.

Dokumen Draft Konsep Tamhidy Kelas I dan IV Madrasah Muallimin Muhammadiyah Yogyakarta T.A. 2012/2013.

Jandra, M. "Islam dalam Konteks Budaya dan Tradisi Plural". dalam buku Zakiyudin Baidhawi, ed., Agama dan Pluralitas Budaya Lokal. Surakarta:Muhammadiyah University Press, 2002.

Nasri, Imron (ed). Pluralisme dan Liberalisme; Pergolakan Pemikiran Anak Muda Muhammmadiyah. Yogyakarta: Citra Karsa Mandiri, 2005.

Parekh, Bikhu. Rethinking Multiculturalism: Cultural Diversity and Political Theory. Cambridge: Harvard University Press, 2000.

Robertson, Roland. Agama dalam Analisa dan Interpretasi Sosiologis, terj. Ahmad Fidyani Saifudin. Jakarta:Rajawali Press. 1988.

Sholahuddin, A. Pesantren dan Budaya Damai. http://www.gp-anshor. org/?p+13308, diakses tanggal 1 oktober 2015.

Silberman, M. Active Learning 101 Strategies to Teach Any Subject. Mancussets: Allyn and Bacoon, 1996.

Team Penyusun. Buku Pedoman Pembinan Siswa Madrasah Mu’allimin Muhammadiyah Yogyakarta.

Wahyuningsih, Austin. Managemen Pendidikan Karakter. Lombok: Elhikam Press, 2015.

\section{List of Informants}

Pesantren Sunan Pandanaran:

Jazilus Sakhok 
Ainun Hakiemah

Siti Zulfah

Ahmad Faizun

Idris Hemay

Ade Supriadi

Teguh Arifiyanto

Nuktohul Huda

Pondok Muallimin Yogyakarta:

Asep Sholahuddin

Ruslan Fariadi

Misbahul Munir

Lathif Rifa’i 